\title{
Measurement of the Maturity Level of IT Governance in Implementing Personnel Management Information System Using the MEA Domain COBIT 5 Framework In Regional Personnel, Education and Training Agency
}

\section{Pengukuran Tingkat Kematangan Tata Kelola TI Dalam Implementasian Sistem Informasi Manajemen Kepegawaian Menggunakan Framework COBIT 5 Domain MEA Pada Badan Kepegawaian, Pendidikan Dan Pelatihan Daerah Kota Salatiga}

\author{
Stanny Dewanty Rehatta ${ }^{1}$, Augie David Manuputty ${ }^{2}$ \\ 1,2Information System Departement, Satya Wacana Christian University \\ Email:1682015021@student.uksw.edu,2augiemanuputty@gmail.com
}

\begin{abstract}
Nowadays the development of Information Technology (IT) is experiencing rapid progress. This development also affect Information Systems (IS). Today Most organizations use and consider IS as an important part of business processes. Regional Personnel, Education and Training Agency (BKDIKLATDA) in Salatiga City is a Personnel Institution located in the Salatiga Municipal Government area which implements IS as the business process support. One of the IS used is the Personnel Management Information System (SIMPEG). SIMPEG is a system specifically designed to provide personnel administration management information quickly, accurately, and has the function to manage staffing data and information within the working environment of the Salatiga Municipal Government. The purpose of this study is to measure the level of maturity of IT governance in the implementation of SIMPEG in BKDIKLATDA. The results of this study indicate that the maturity level of the MEA01 and MEA03 processes reached 3.70 and 3.55 at level 4, which has been carried out within the specified limits to achieve the expected outcomes. And in the MEA02 process, it reaches 3.36, which is at level 3, where this process has been implemented using certain predetermined processes, which are able to achieve the expected outcomes. Recommendations given in general are expected to be used as input so that they can help improve the quality of IT governance in implementing SIMPEG.
\end{abstract}

Keywords: IT Governance, COBIT 5, MEA Domain

This work is licensed under a Creative Commons Attribution 4.0 International License. 


\section{PENDAHULUAN}

Dewasa ini perkembangan Teknologi Informasi (TI) mengalami kemajuan yang pesat. Perkembangan ini juga yang memberi pengaruh bagi Sistem Informasi (SI). Sebagian besar organisasi saat ini menggunakan SI dan menganggap SI sebagai bagian penting dalam proses bisnis [1]. SI merupakan salah satu penunjang bagi suatu organisasi untuk mendukung dan membantu dalam memaksimalkan proses bisnis dan merealisasikan tujuan dari organisasi. SI yang tepat sanggat diperlukan untuk membantu sebuah organisasi dalam pengambilan keputusan dan merealisasikan pencapaian tujuan bisnisnya [2].

Badan Kepegawaian, Pendidikan dan Pelatihan Daerah (BKDIKLATDA) Kota Salatiga merupakan Lembaga Kepegawaian yang berada di wilayah Pemerintah Kota Salatiga. BKDIKLATDA dibentuk berdasarkan Keputusan Presiden Nomor 159 Tahun 2000 tentang pedoman pembentukan Badan Kepegawaian Daerah dan Peraturan Daerah Nomor 6 Tahun 2001 tentang pembentukan Lembaga teknis Daerah Kota Salatiga. BKDIKLATDA saat ini sudah mengimplementasikan SI sebagai pendukung proses bisnis. Salah satu SI yang digunakan yaitu Sistem Informasi Manajemen Kepegawaian (SIMPEG). SIMPEG merupakan sebuah sistem yang yang dirancang khusus untuk menyediakan informasi manajemen administrasi kepegawaian secara cepat, tepat dan akurat, dan mempunyai fungsi untuk mengelola data dan informasi kepegawaian yang berada di lingkungan kerja Pemerintah Daerah Kota Salatiga. SIMPEG sendiri dikembangkan kedalam modul-modul sesuai dengan regulasi yang ada, SIMPEG diterapkan di BKDIKLATDA sejak tahun 2005, kemudian di tahun 2013 SIMPEG dikembangkan secara online dan dapat diakses melalui website (http://simpeg.salatiga.go.id).

Dalam penerapan SIMPEG, dibutuhkan suatu kerangka kerja yang dapat digunakan untuk menilai kualitas tata kelola TI. Kerangka kerja yang dapat digunakan antara lain COBIT, ITIL, ISO dan lainnya. Pada penelitian ini kerangka kerja yang digunakan yaitu COBIT 5. COBIT 5 dipilih karena merupakan kerangka kerja yang berupa produk panduan best practices yang menyajikan kegiatan dalam struktur organisasi TI yang dikelola dan logis, disusun oleh para ahli di bidang tata kelola TI, dan lebih berfokus pada kontrol, bukan pada eksekusi. Praktek ini akan membantu mengoptimalkan investasi TI, memastikan penyampaian layanan dan memberikan ukuran terhadap yang bisa dilakukan untuk menilai ketika terjadi kesalahan [3].

Adapun kendala maupun masalah yang membuat implementasian SIMPEG kurang begitu optimal yaitu dari ketidaksesuaianya data kepegawaian dilapangan dan data yang ada pada sistem, selain itu terbatasnya SDM yang mengakibatkan tumpang tindihnya pekerjaan, dalam hal ini pengelolaan manajemen administrasi kepegawaian menjadi tidak fokus sehingga statistik data kepegawaian tidak valid yang mempengaruhi dalam proses pengambilan keputusan. Berdasarkan masalah tersebut, pada penelitian ini akan digunakan kerangka kerja COBIT 5 khususnya 
domain Monitor, Evaluate, Assessment (MEA) guna melakukan pengamatan, evaluasi dan penilaian tata kelola TI dalam implementasian SIMPEG di BKDIKLATDA. MEA merupakan suatu domain pada COBIT 5 yang tujuannya adalah untuk melakukan pengamatan, mengevaluasi dan menilai semua proses yang berkaitan dengan TI dalam suatu perusahan atau organisasi [4]. Tujuan dari penelitian ini untuk mengukur tingkat kematangan tata kelola TI dalam implementasian SIMPEG di BKDIKLATDA. Hasil dari penelitian ini diharapkan dapat memberikan kontribusi secara akademis bagi Pemerintah Kota Salatiga, khususnya BKDIKLATDA Kota Salatiga.

\section{METODOLOGI PENELITIAN}

\subsection{Metode Pengumpulan Data}

Penelitian ini menggunakan metode mixed method, yang merupakan pendekatan penelitian yang menggabungkan atau menghubungkan metode penelitian kualitatif dan kuantitatif [5]. Data kualitatif yang diperoleh dalam penelitian yaitu dari teknik pengumpulan data berupa hasil wawancara dan observasi. Wawancara dilakukan untuk memperoleh informasi secara langsung dari responden penelitian. Observasi dilakukan untuk mengamati secara langsung objek penelitian. Sedangkan data kuantitatif berupa data yang diperoleh dari hasil kuesioner yang mengacu pada domain MEA, yang kemudian diolah atau dianalisis menggunakan perhitungan matematik, untuk mengetahui tingkat kematangan yang dimiliki. Objek penelitian ditentukan berdasarkan acuan RACI Chart pada COBIT 5. RACI Chart merupakan matriks dari semua aktivitas dan wewenang pada organisasi yang membantu dalam mengambil keputusan [5]. Ruang lingkup penelitian ini dibatasi pada pengukuran tingkat kematangan domain MEA. Hasil dari penelitian ini berupa rekomendasi yang dibuat berdasarkan kondisi tata kelola TI dalam implementasian SIMPEG di BKDIKLATDA.

\subsection{Tahapan Penelitian}

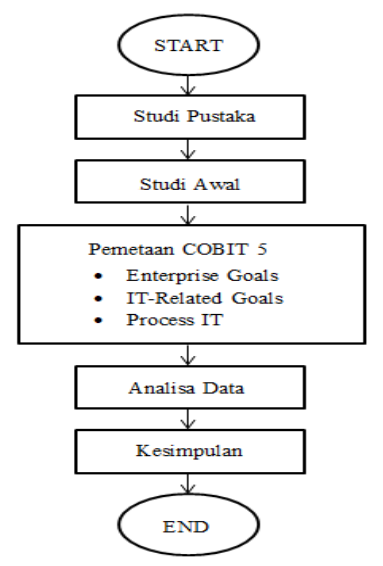

Gambar 1. Tahapan Penelitian 
Tahap I Studi Pustaka yaitu dengan memahami dan mempelajari teori-teori manajemen dan tata kelola TI serta pemahaman tentang framework COBIT 5 khususnya domian MEA yang dijadikan fokus dalam penelitian di BKDIKLATDA.

Tahap II Studi Awal yaitu dengan melakukan observasi objek penelitian untuk mendapatkan data organisasi meliputi visi, misi organisasi serta bagaimana proses bisnis saat ini yang sedang berjalan, selanjutnya melakukan wawancara untuk menganalisa kebutuhan stakebolder yang berkaitan dengan tujuan SIMPEG, kemudian memberikan kuesioner kepada responden yang kesehariannya mengoperasikan SIMPEG dan juga yang berasal dari unit kerja lain yang berkaitan.

Tahap III Pemetaan COBIT 5 yaitu dengan mengidentifikasi Enterprise Goals terpilih berdasarkan analisa kebutuhan stakebolder yang berkaitan dengan tujuan SIMPEG, kemudian dari Enterprise Goals terpilih tersebut dilakukan identifikasi terhadap IT-Related Goals, dari IT-Related Goals terpilih kemudian dilakukan pemetaan Enterprise Goals kedalam IT-Related Goals, selanjutnya dilakukan identifikasi COBIT 5 proses terpilih dengan memilih nilai primary $(\mathrm{P})$ pada proses domain yang terpilih, akan tetapi penelitian ini berfokus hanya pada satu domain yaitu domian MEA, maka COBIT 5 proses yang dipilih hanya domain MEA.

Tahap IV Analisa Data yaitu dengan melakukan perhitungan tingkat kematangan pada domain MEA01, MEA02, MEA03 yang dilakukan berdasarkan Process Capability Model yaitu dengan melakukan perhitungan terhadap hasil kuesioner yang didapat dari responden penelitian.

Tahap V Kesimpulan yaitu dengan menyimpulkan kedalam bentuk rangkuman berdasarkan analisa data yang dilakukan yang kemudian menghasilkan rekomendasi perbaikan kualitas tata kelola TI dalam implementasi SIMPEG di BKDIKLATDA.

\subsection{Responden Penelitian}

Responden yang terlibat dalam pengisian kuesioner ini mengacu pada RACI Responsible, Accountable, Consulted, Informed, dimana meliputi pegawai yang kesehariannya secara langsung mengoperasikan SIMPEG dan juga yang berasal dari unit kerja lain yang berkaitan.

Tabel 1. Responden Berdasarkan RACI chart

\begin{tabular}{|c|c|c|c|}
\hline RACI & Fungsi dan Peran & Nama Responden & Jabatan \\
\hline Responsible & $\begin{array}{l}\text { Menjelaskan tentang } \\
\text { siapa yang bertanggung } \\
\text { jawab atas tugas yang } \\
\text { diberikan }\end{array}$ & $\begin{array}{c}\text { Bpk. Mursyid } \\
\text { Bpk. Teguh }\end{array}$ & $\begin{array}{l}\text { Staf Sub Bidang } \\
\text { Pengelolaan Data } \\
\text { dan Informasi }\end{array}$ \\
\hline
\end{tabular}


Vol. 1, No. 2, September 2019

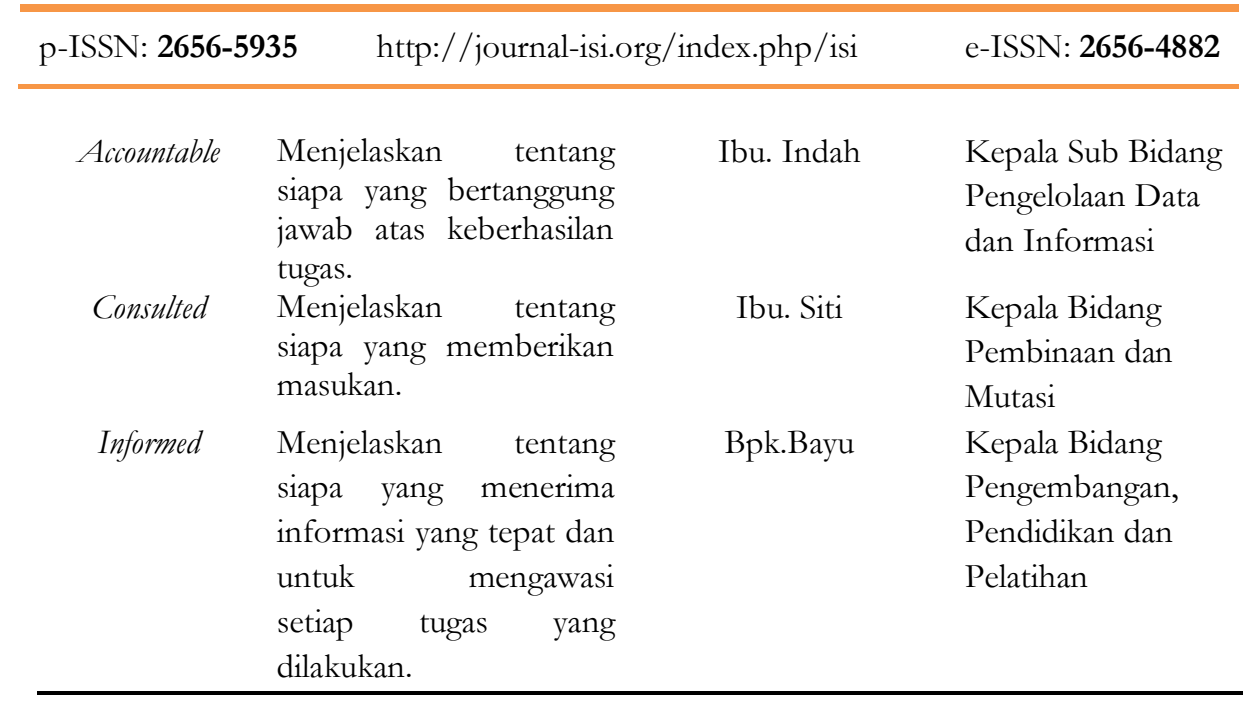

\section{HASIL DAN PEMBAHASAN}

BKDIKLTADA Kota Salatiga memiliki visi yaitu "Terwujudnya Kepemerintahan yang baik (Good Governance) melalui aparatur yang akuntabel dan profesional”. Misi BKDIKLTADA Kota Salatiga antara lain yaitu: Meningkatkan kualitas Sumber Daya Aparatur, Mewujudkan penataan Pegawai Negeri Sipil (PNS) dalam jabatan sesuai kompetensinya, Meningkatkan pelayanan prima administrasi kepegawaian dalam rangka mewujudkan pelayanan administrasi yang tepat didukung oleh penyajian data dan informasi kepegawaian yang akurat, Meningkatkan pembinaan Aparatur dalam rangka mendorong peningkatan disiplin dan kesejahteraan PNSD. Berdasarkan visi, misi organisasi, maka dilakukan analisa terhadap kebutuhan stakeholder yang memiliki prioritas tinggi yang berkaitan dengan tujuan SIMPEG. yang kemudian dianalisa menggunakan Balanced Scorecard (BSC) yang memiliki 4 dimension antara lain: Financial, Customer, Internal dan Learning \& Growth.

Tabel 2. Pemetaan Enterprise Goals (EG) COBIT 5 dengan Tujuan SIMPEG

\begin{tabular}{|c|c|c|c|}
\hline $\begin{array}{c}\text { BSC } \\
\text { Dimension }\end{array}$ & $\begin{array}{c}\text { EG } \\
\text { Terpilih }\end{array}$ & $\begin{array}{c}\text { Keterkaitan dengan Tujuan } \\
\text { SIMPEG }\end{array}$ & Tujuan SIMPEG \\
\hline Financial & $\begin{array}{c}\text { EG3 } \\
\text { Managed } \\
\text { business risk } \\
\text { (safeguarding of } \\
\text { assets) }\end{array}$ & $\begin{array}{l}\text { Memiliki keterkaitan dengan } \\
\text { tujuan SIMPEG dimana untuk } \\
\text { menjaga kelangsungan layanan } \\
\text { SIMPEG dilakukan } \\
\text { pengelolaan dan pemeliharaan } \\
\text { terhadap aset yang dimiliki. }\end{array}$ & $\begin{array}{l}\text { Menjaga kelangsungan } \\
\text { layanan SIMPEG }\end{array}$ \\
\hline Customer & $\begin{array}{l}\text { EG7 } \\
\text { Busniness } \\
\text { service } \\
\text { continuity and }\end{array}$ & $\begin{array}{l}\text { Memiliki keterkaitan dengan } \\
\text { tujuan SIMPEG dimana untuk } \\
\text { memberikan pelayanan yang } \\
\text { mudah dalam pelaksanaan } \\
\text { manajemen }\end{array}$ & $\begin{array}{l}\text { Memberikan pelayanan } \\
\text { yang mudah dalam } \\
\text { pelaksanaan manajemen } \\
\text { administrasi }\end{array}$ \\
\hline
\end{tabular}


Vol. 1, No. 2, September 2019

\begin{tabular}{|c|c|c|c|}
\hline \multicolumn{2}{|c|}{ p-ISSN: 2656-5935 } & http://journal-isi.org/index.php/isi & e-ISSN: 2656-4882 \\
\hline & availability & $\begin{array}{l}\text { kepegawaian secara cepat dan } \\
\text { tepat. }\end{array}$ & $\begin{array}{l}\text { kepegawaian secara } \\
\text { cepat dan tepat. }\end{array}$ \\
\hline Internal & $\begin{array}{c}\text { EG15 } \\
\text { Compliance } \\
\text { with internal } \\
\text { police }\end{array}$ & $\begin{array}{l}\text { Memiliki keterkaitan dengan } \\
\text { tujuan SIMPEG karena dalam } \\
\text { menjalankan proses bisnis, } \\
\text { SIMPEG memiliki standard } \\
\text { operational product (SOP) yang } \\
\text { digunakan sebagai acuan } \\
\text { pelaksanaan proses bisnis. }\end{array}$ & $\begin{array}{l}\text { Memiliki SOP (standard } \\
\text { operational product) yang } \\
\text { digunakan sebagai acuan } \\
\text { pelaksanaan proses } \\
\text { bisnis. }\end{array}$ \\
\hline $\begin{array}{c}\text { Learning \& } \\
\text { Growth }\end{array}$ & $\begin{array}{c}\text { EG16 } \\
\text { Skilled and } \\
\text { motivated } \\
\text { people }\end{array}$ & $\begin{array}{lrr}\text { Memiliki keterkaitan } & \text { dengan } \\
\text { tujuan SIMPEG } & \text { untuk } \\
\text { meningkatkan kualitas } & \text { sumber } \\
\text { daya manusia (SDM) melalui } & \text { pelatihan-pelatihan } & \text { yang } \\
\text { dilakukan oleh lembaga yang } & \\
\text { bekerja sama dengan } \\
\text { Pemerintah Kota Salatiga agar } \\
\text { proses bisnis berjalan dengan } \\
\text { lancar. }\end{array}$ & $\begin{array}{l}\text { Meningkatkan kualitas } \\
\text { sumber daya manusia } \\
\text { (SDM) melalui } \\
\text { pelatihan-pelatihan yang } \\
\text { dilakukan oleh lembaga } \\
\text { yang bekerja sama } \\
\text { dengan Pemerintah Kota } \\
\text { Salatiga agar proses } \\
\text { bisnis berjalan lancar. }\end{array}$ \\
\hline
\end{tabular}

Berdasarkan Enterprise Goals terpilih, kemudian dilakukan pemetaan kedalam ITRelated Goals (ITRG). Hasil pemetaan dapat dilihat pada Tabel 3 berikut.

Tabel 3. Pemetaan Enterprise Goals kedalam IT-Related Goals

\begin{tabular}{ll}
\hline EG Terpilih & \multicolumn{1}{c}{ ITRG Terpilih } \\
\hline EG3 & ITRG04, ITRG10, ITRG16 \\
EG7 & ITRG04, ITRG10, ITRG14 \\
EG15 & ITRG02, ITRG10, ITRG15 \\
EG16 & ITRG16 \\
\hline
\end{tabular}

Tabel 4. Deskripsi hasil pemetaan IT-Related Goals Terpilih

\begin{tabular}{ll}
\hline Kode & \multicolumn{1}{c}{ Deskripsi } \\
\hline ITRG02 & $\begin{array}{l}\text { IT compliance and support for business compliance with external } \\
\text { laws and regulations }\end{array}$ \\
ITRG04 & Managed IT-related business risk \\
ITRG10 & Security of information, processing infrastructure and applications \\
ITRG14 & Availability of reliable and useful information for decision making \\
ITRG15 & IT compliance with internal policies \\
ITRG16 & Competent and motivated business and IT personnel \\
\hline
\end{tabular}


Vol. 1, No. 2, September 2019

p-ISSN: 2656-5935 http://journal-isi.org/index.php/isi e-ISSN: 2656-4882

Selanjutnya melakukan pemetaan IT-Related Goals kedalam COBIT 5 Process kemudian dipilih nilai primary (P). Pemetaan tersebut dapat dilihat pada Tabel 5 berikut ini.

Tabel 5. Pemetaan IT-Related Goals kedalam COBIT 5 Process

ITRG Terpilih COBIT 5 Process

\begin{tabular}{ll}
\hline ITRG02 & MEA02, MEA03 \\
ITRG04 & MEA01, MEA02, MEA03 \\
ITRG15 & MEA01, MEA02 \\
\hline
\end{tabular}

Tabel 6. Deskripsi hasil pemetaan COBIT 5 Process

\begin{tabular}{ll}
\hline Kode & \multicolumn{1}{c}{ Deskripsi } \\
\hline MEA01 & Monitor, Evaluate and Assess Performance and Conformance \\
MEA02 & Monitor, Evaluate and Assess The System of Internal Control \\
MEA03 & Monitor, Evaluate and Assess Compliance with External \\
& Requirements \\
\hline
\end{tabular}

Berdasarkan COBIT 5 process terpilih (domain MEA) dilakukan perhitungan tingkat kematangan menggunakan Process Capability Model, model ini digunakan untuk mencapai tujuan secara keseluruhan dari proses penilaian dan proses peningkatan [6]. Hasil dari kuesioner yang dibagikan kepada responden kemudian dilakukan perhitungan terhadap tingkat kematangan. Persamaan matematik yang digunakan untuk menghitung tingkat kematangan pada masingmasing domain MEA dalam penelitian ini adalah:

$$
\text { Indeks }=\frac{\sum \text { Jawaban Kuesioner }}{\sum \text { Pertanyaan Kuesioner }}
$$

Hasil perhitungan tingkat kematangan COBIT 5 domain MEA adalah sebagai berikut:

Tabel 7. Tingkat Kematangan MEA01

\begin{tabular}{clc}
\hline Proses & \multicolumn{1}{c}{ Aktivitas } & $\begin{array}{c}\text { Tingkat } \\
\text { Kematangan }\end{array}$ \\
\hline MEA01.01 & $\begin{array}{l}\text { Pendekatan pemantauan dilakukan oleh staff yang ada } \\
\text { untuk mengukur tingkat kinerja SIMPEG agar sesuai }\end{array}$ & 3,47 \\
dengan tujuan instansi & $\begin{array}{l}\text { Mengatur dan monitoring secara berkala, melakukan } \\
\text { update terhadap kesesuaian target dalam pengukuran }\end{array}$ & 3,96
\end{tabular}


Vol. 1, No. 2, September 2019

\begin{tabular}{llll}
\hline p-ISSN: 2656-5935 http://journal-isi.org/index.php/isi & e-ISSN: 2656-4882 \\
\hline MEA01.03 & $\begin{array}{l}\text { kengumpulkan dan memproses data kinerja dan } \\
\text { kesesuaian }\end{array}$ & 3,82 \\
MEA01.04 & $\begin{array}{l}\text { Melakukan analisis dan melaporkan proses kinerja } \\
\text { MEA01.05 }\end{array}$ & 3,53 \\
& $\begin{array}{l}\text { Memastikan pelaksanaan tindakan perbaikan yaitu } \\
\text { mengidentifikasi, memulai pelacakan dan melakukan } \\
\text { tindakan perbaikan untuk tujuan yang tidak sesuai. }\end{array}$ & 3,76 \\
\hline
\end{tabular}

Tabel 7 merupakan hasil perhitungan tingkat kematangan domain MEA01 (Monitor, Evaluate, and Asses Performance and Conformance). Pada domain MEA01 tingkat kematangan yang dimiliki yaitu 3,70 dari rentang 0-5 dengan process capability model yang dicapai adalah pada level 4 predictable process, yang dimana proses ini telah dijalankan dalam batasan yang ditentukan untuk mencapai outcome yang diharapkan. Seperti yang diungkapkan oleh Staff Sub Bidang Pengelolaan Data dan Informasi, Bapak Teguh dalam wawancara sebagai berikut:

“..Untuk proses pelaporan kinerja SIMPEG kita lakukan secara sistematis dan tepat waktu tetapi kondisional, jadi misalnya kita memang laporan setiap akbir tabun ada laporan data pegawai dan sistem dalam hal ini pengembangan kita laporkan juga per selesai kegiatan dan pada akbir tahun". ${ }^{1}$

Hal ini menunjukan bahwa penerapan SIMPEG di BKDIKLATDA Kota Salatiga sudah dilakukan monitoring, evaluasi, dan penilaian kinerja proses TI dengan baik, dapat dilihat dari dari tercapainya tujuan SIMPEG yang telah direncanakan. Tujuan yang diharapkan yaitu memberikan pelayanan yang mudah dalam pelaksanaan manajemen administrasi kepegawaian secara cepat dan tepat, selain itu pelaporan kinerja SIMPEG telah dilakukan secara sistematis dan tepat waktu.

Tabel 8. Tingkat Kematangan MEA02

\begin{tabular}{cllc}
\hline Proses & \multicolumn{1}{c}{ Aktivitas } & $\begin{array}{c}\text { Tingkat } \\
\text { Kematangan }\end{array}$ \\
\hline MEA02.01 & $\begin{array}{l}\text { Memantau dan meningkatkan pengendalian TI untuk } \\
\text { memenuhi tujuan instansi. }\end{array}$ & 3,65 \\
MEA02.02 & $\begin{array}{l}\text { Mengontrol efektivitas dari proses bisnis SIMPEG. } \\
\text { Kegiatan ini meliputi kontrol secara periodik, mengontrol } \\
\text { secara terus-menerus. }\end{array}$ & 3,65 \\
\end{tabular}

\footnotetext{
${ }^{1}$ Hasil wawancara dengan Bapak Teguh pada tanggal 29 Juli 2019 di Salatiga
} 
Vol. 1, No. 2, September 2019

p-ISSN: 2656-5935 http://journal-isi.org/index.php/isi

e-ISSN: 2656-4882

MEA02.03 Manajemen atau staff dalam instansi melakukan perbaikan kontrol melalui program berkelanjutan. Penilaian digunakan untuk mengevaluasi pengendalian proses 3,65 manajemen.

MEA02.04 Mengidentifikasi dan melaporkan kekurangan kontrol dilakukan dari akar penyebab yang mendasari suatu masalah.

MEA02.05 Memastikan bahwa instansi melakukan asuransi yang independen dan berkualitas dari fungsi dalam lingkup kelompok atau organisasi.

MEA02.06 Inisiatif rencana jaminan berdasarkan dengan kinerja instansi, tujuan jaminan, terbatasnya sumber daya, dan pengetahuan yang cukup.

MEA02.07 Inisiatif cakupan jaminan berdasarkan dengan tujuan jaminannya.

MEA02.08 Instansi telah melakukan kegiatan jaminan untuk melakukan kinerja dan memenuhi tujuan yang berkualitas.

\section{Rata-Rata Tingkat Kematangan}

Tabel 8 merupakan hasil perhitungan tingkat kematangan domain MEA02 (Monitor, Evaluate, and Asses The System of Internal Control). Pada domain MEA02 tingkat kematangan yang dimiliki yaitu 3,36 dari rentang 0-5 dengan process capability model yang dicapai adalah pada level 3 established process, yang dimana proses ini telah diimplementasikan menggunakan proses tertentu yang telah ditetapkan, yang mampu mencapai outcome yang diharapkan. Seperti yang diungkapkan oleh Staff Sub Bidang Pengelolaan Data dan Informasi, Bapak Teguh dan Bapak Mursyid dalam wawancara sebagai berikut:

“..Kalau untuk kinerja proses SIMPEG kita ada dua pendokumentasian, berupa pengembangan sistem dan manual book. Untuk manual book diberikan kepada atasan dan kantor-kantor lain, kalau untuke pengembangan sistem itu nanti dari sini diserabkan kepada KOMINFO untuk kontrol pengembangan aplikasi". ${ }^{2}$

“..Kurangnya SDM membuat Sub Bidang Pengelolaan Data dan Informasi disini menjadi tidak fokus dalam melakukan maintanance data, jadi satu pegawai ada yang mengerjakan lebih dari satu pekerjaan. Nah hal tersebut yang membuat sehingga statistik. data kepegawaian itu menjadi tidak valid yang dimana susah dalam pengambilan keputusan". 3

\footnotetext{
${ }^{2}$ Hasil wawancara dengan Bapak Teguh pada tanggal 29 Juli 2019 di Salatiga

${ }^{3}$ Hasil wawancara dengan Bapak Mursyid pada tanggal 05 Agustus 2019 di Salatiga
} 
Vol. 1, No. 2, September 2019

p-ISSN: 2656-5935 http://journal-isi.org/index.php/isi e-ISSN: 2656-4882

Hal ini menunjukan bahwa penerapan SIMPEG di BKDIKLATDA Kota Salatiga sudah dilakukan monitoring, evaluasi, dan penilaian sistem pengendalian internal dengan baik, dapat dilihat dari dilakukannya pendokumentasian yang dilakukan terkait dengan proses internal kontrol, akan tetapi masih terdapat kekurangan SDM pranta komputer pada Sub Bidang Pengelolaan Data dan Informasi yang mengakibatkan tumpang tindihnya pekerjaan. Sehingga fokus pengelolaan manajemen SIMPEG menjadi sulit dalam hal pengambilan keputusan.

Tabel 9. Tingkat Kematangan MEA03

\begin{tabular}{clc}
\hline Proses & \multicolumn{1}{c}{ Aktivitas } & \multicolumn{1}{c}{$\begin{array}{c}\text { Tingkat } \\
\text { Kematangan }\end{array}$} \\
\hline MEA03.01 & $\begin{array}{l}\text { Mengidentifikasi dan memantau secara terus-menerus } \\
\text { terhadap perubahan dalam hukum, peraturan lokal } \\
\text { dan internasional, serta persyaratan eksternal lainnya }\end{array}$ & 3,65 \\
yeng mesti dipenuhi dari sudut pandang TI. & \\
Meninjau dan menyesuaikan peraturan, prinsip, \\
prosedur, serta metodelogi guna memastikan bahwa \\
$\begin{array}{l}\text { persyaratan eksternal dalam hal ini setiap peraturan } \\
\text { yang terkait di dikomunikasikan. mempertimbangkan } \\
\text { setiap standar, kode serta panduan praktik yang baik }\end{array}$ & 3,53 \\
untuk dilakukan adopsi dan adaptasi. \\
$\begin{array}{l}\text { Mengkonfirmasikan kepatuhan terhadap setiap } \\
\text { kebijakan maupun standar dan prosedur yang berlaku } \\
\text { dengan setiap persyartan hukum, peraturan dan } \\
\text { kontrak } \\
\text { Mendapatkan dan melaporkan jaminan kepatuhan dan } \\
\text { kepatuhan terhadap kebijakan, prinsip, standar, } \\
\text { prosedur dan metodologi. Memastikan bahwa } \\
\text { tindakan korektif untuk mengatasi kesenjangan } \\
\text { kepatuhan ditutup pada waktu yang tepat. }\end{array}$ & 3,53 \\
\hline Rata-Rata Tingkat Kematangan & 3,47 \\
\hline MEA03.04 & $\mathbf{3 , 5 5}$ \\
\hline
\end{tabular}

Tabel 9 merupakan hasil perhitungan tingkat kematangan domain MEA03 (Monitor, Evaluate, and Asses Compliance with External Requirements). Pada domain MEA03 tingkat kematangan yang dimiliki yaitu 3,55 dari rentang 0-5 dengan process capability model yang dicapai adalah pada level 4 predictable process, yang dimana proses ini telah dijalankan dalam batasan yang ditentukan untuk mencapai outcome yang diharapkan. Seperti yang diungkapkan oleh Staff Sub Bidang Pengelolaan Data dan Informasi, Bapak Teguh dalam wawancara sebagai berikut: 
Vol. 1, No. 2, September 2019

p-ISSN: 2656-5935 http://journal-isi.org/index.php/isi

e-ISSN: 2656-4882

“..Jadi SIMPEG ini berjalan sesuai dengan regulasi dari pusat, kita mengikuti regulasi dari BKN. SIMPEG ini sistemnya kita kembangkan sendiri sesuai aturan-aturan yang dibuat dari pusat. Dalam rapat tabunan juga membahas mengenai persyaratan, kepatuban dan dampak setiap aktivitas TI”.4
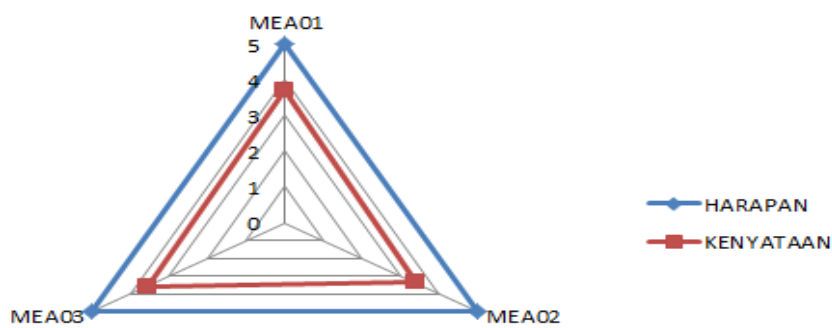

Grafik 1. Hasil Pengukuran Process Capability Model Kedalam Bentuk Grafik

Dari hasil perhitungan tingkat kematangan, maka dilakukan analisa terhadap kesenjangan yang bertujuan untuk mengetahui tingkat GAP yang dapat dilihat pada Tabel 10 sebagai berikut.

Tabel 10. Analisa Kesenjangan Terhadap Tingkat GAP

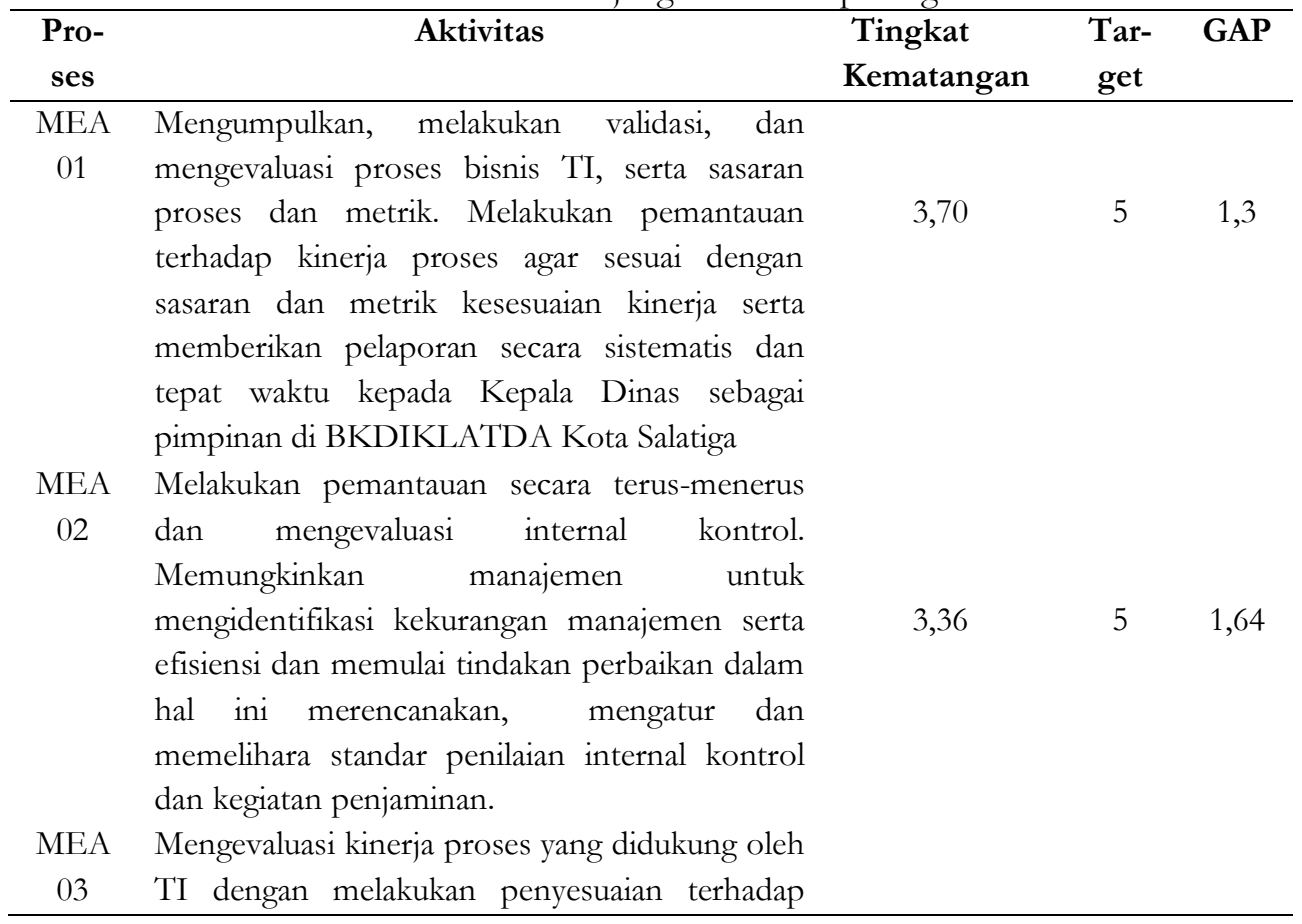

\footnotetext{
${ }^{4}$ Hasil wawancara dengan Bapak Teguh pada tanggal 29 Juli 2019 di Salatiga
} 
Vol. 1, No. 2, September 2019

\begin{tabular}{llccr}
\hline p-ISSN: 2656-5935 http://journal-isi.org/index.php/isi & e-ISSN: 2656-4882 \\
\hline & & 3,55 & 5 & 1,45 \\
persyaratan eksternal yang berupa kepatuhan & & & \\
terhadap peraturan, undang-undang dan & & & \\
persyaratan kontrak. Mendapatkan jaminan \\
bahwa persyaratan sudah diidentifikasi, dipatuhi \\
serta diintegrasikan secara menyeluruh.
\end{tabular}

\section{KESIMPULAN DAN SARAN}

\subsection{Kesimpulan}

Berdasarkan hasil perhitungan tingkat kematangan, dilakukan analisa terhadap kesenjangan untuk mengetahui tingkat GAP, pada MEA01 (Monitor, Evaluate and Assess Performance and Conformance) dengan rata-rata tingkat kematangan saat ini mencapai angka 3,70 dengan process capability model dicapai pada level 4 predictable process dengan GAP yang dimiliki sebesar 1,3. Pada MEA02 (Monitor, Evaluate and Assess The System of Internal Control) dengan rata-rata tingkat kematangan mencapai angka 3,36 dengan process capability model dicapai pada level 3 established process dengan GAP yang dimiliki sebesar 1,64. Pada MEA03 (Monitor, Evaluate and Assess Compliance with External Requirements) dengan rata-rata tingkat kematangan mencapai angka 3,55 dengan process capability model dicapai pada level 4 predictable process dengan GAP yang dimiliki sebesar 1,45. Dari hasil perhitungan terhadap tingkat kematangan yang dilakukan, target yang diharapkan dapat dicapai pada masing-masing domain yaitu pada level 5 (optimising process). Berdasarkan hasil perhitungan serta kesimpulan yang telah dikemukakan, berikut rekomendasi secara umum yang diharapkan dapat memberikan kontribusi secara akademis bagi Pemerintah Kota Salatiga khususnya Badan Kepegawaian, Pendidikan dan Pelatihan Daerah antara lain: Melakukan evaluasi dan pemantauan terhadap kinerja sistem terus-menerus secara rutin dan bertahap. Melakukan pendokumentasian terhadap pemeliharaan tata kelola TI. Menerapkan framework COBIT dalam mengoptimalkan kualitas tata kelola TI. Meningkatkan SDM untuk memenuhi kebutuhan manajemen dan pengelolaan TI. Meningkatkan kualitas SDM melalui pelatihan-pelatihan yang dilakukan secara berkala seiring dengan berkembangnya sistem.

\subsection{Saran}

Saran untuk penelitian yang akan datang dengan judul atau topik yang mengacu pada penelitian ini kedepannya yaitu tidak hanya terfokus pada satu domain, tetapi dapat menggunakan domain COBIT 5 lainnya seperti EDM, APO, BAI, DSS. Selain itu juga dapat dilakukan analisa/evaluasi terhadap sistem infromasi yang diterapkan di BKDIKLATDA Kota Salatiga seperti SIMDIKLAT, SICUTE, KGB Online, dan lainnya. 


p-ISSN: 2656-5935 http://journal-isi.org/index.php/isi e-ISSN: 2656-4882

\section{DAFTAR PUSTAKA}

[1] Andani, Anneke T; Agustinus F Wijaya, "Evaluasi Kinerja Sistem Informasi E-Filling Menggunakan COBIT 5 Pada Kantor Pelayanan Pajak Pratama", JUTEI Vol 1 No 1, 2017.

[2] Septiana, Laxmi C; Andeka R Tanaamah, "Perencanaan Strategis Sistem Informasi Menggunakan Kerangka The Open Group Architecture Framework (TOGAF) pada BPJS Kesehatan Surakarta", Salatiga: Universitas Kristen Satya Wacana, 2015.

[3] Tagatari, Yola V; Yani Rahardja; Agustinus F Wijaya, "Evaluasi Kinerja Sistem Informasi Manajemen Operasional Pelabuhan Menggunakan COBIT 5 pada PT. Pelabuhan Indonesia II (Persero) Cabang Panjang Lampung", Salatiga: Universitas Kristen Satya Wacana, 2018.

[4] Belegur, Juan A I; Chris Rudianto; Melkior N N Sitokdana, "Evaluasi Tata Kelola Teknologi Informasi Dinas Pariwisata dan Kebudayaan Kota Ambon Menggunakan Framework Cobit 5.0 pada Domain Monitor, Evaluate And Asses (MEA)", AITI Vol 15 No 2, 2018.

[5] Noya, Stephanie A. Ariya Dwika Cahyono. dkk. 2018. Evaluasi Kinerja Tata Kelola Teknologi Informasi Pada Dinas Perindustrian Dan Tenaga Kerja Kota Salatiga. Jurnal Sistem Informasi Indonesia (JSII) Volume 3 Nomor 1.

[6] Sugiyono, "Metode Penelitian Kuantitatif, Kualitatif, Dan Kombinasi (Mixed Methods)", Bandung: Alfabeta, 2012.

[7] ISACA, COBIT 5, "A Business Framework for the Governance and Management of Enterprise IT ”,USA: ISACA, 2012. 